\title{
Varicella-zoster virus infection: more than just a rash
}

\author{
Diana H Silva 도 , Denise Banganho 다 , Biana Moreira, Ana Gomes Silva
}

Department of Pediatrics, Hospital de São Bernardo, Centro Hospitalar de Setúbal EPE, Setubal, Portugal

Correspondence to Dr Denise Banganho; denise_banganho@hotmail.com

Accepted 25 January 2022

Check for updates

(c) BMJ Publishing Group

Limited 2022. No commercial re-use. See rights and permissions. Published by BMJ.

\footnotetext{
To cite: Silva $\mathrm{DH}$,

Banganho D, Moreira B,

et al. BMJ Case Rep

2022;15:e247006.

doi:10.1136/bcr-2021-

247006
}

\section{DESCRIPTION}

A 16-year-old healthy female presented to the emergency department (ED) due to 3 days of right neck pain and 1 day of pruriginous submandibular and periauricular vesiculopustular rash. She had an up-to-date Portuguese vaccination schedule, without chickenpox vaccine. Admitting herpes zoster (HZ), oral acyclovir $20 \mathrm{mg} / \mathrm{kg} /$ day was started but the patient returned to the ED on the second day of treatment without signs of improvement. Physical examination revealed a vesiculopustular rash on the right side of the face, neck and ear, and small vesiculopustular lesions on the left upper limb and upper left quadrant of the abdomen (figure 1). The ear lesions had purulent drainage.

Considering HZ with severe skin involvement and superinfection of the ear, the patient started intravenous acyclovir $20 \mathrm{mg} / \mathrm{kg} / \mathrm{day}$ and flucloxacillin $150 \mathrm{mg} / \mathrm{kg} /$ day. Hours later confusion was noticed, with temporal disorientation, retrograde amnesia for important events in her life and misrecognition of some family members. Throughout she had no fever nor any other symptoms. Blood tests showed only a mild raise of the C reactive protein ((CRP) $2.34 \mathrm{mg} / \mathrm{dL}$, leucocytes $4.300 \times 10^{3} / \mu \mathrm{L}$, neutrophiles $\left.58 \%(2.494)\right)$ and a peripheral blood smear showed $35 \%$ atypical lymphocytes. PCR of the whole blood and serologies were both positive for varicella-zoster virus (VZV). Serologies for human immunodeficiency virus (HIV) 1 and 2, cytomegalovirus (CMV), herpes simplex virus (HSV) and enterovirus were negative for acute disease. A respiratory panel (real-time PCR/FilmArray) for some of the most common respiratory agents (including Adenovirus, Coronavirus 229E, HKU1, NL63, MERS and OC43, human metapneumovirus, rhinovirus/enterovirus, influenza virus $\mathrm{A} / \mathrm{B}$, parainfluenza virus $1 / 2 / 3 / 4$, respiratory syncytial virus, Bordetella parapertussis and Bordetella pertussis, Chlamydia pneumoniae and Mycoplasma pneumoniae) was negative. A cranial CT scan showed no abnormalities.

The cerebrospinal fluid (CSF) examination revealed lymphocytic pleocytosis (24 white cells/ $\mu \mathrm{L}, 75 \%$ lymphocytes), normal protein concentration $(0.46 \mathrm{~g} / \mathrm{L})$ and normal glucose concentration $(0.72 \mathrm{~g} / \mathrm{L}$; blood glucose $1.02 \mathrm{~g} / \mathrm{L})$. PCR of VZV was positive in CSF. PCR of HSV 1 and 2, human herpes virus 6, CMV and Epstein-Barr virus in CSF were negative and cultures were sterile. The patient was discharged on the 10th day with clinical improvement (figure 2A) and without neurological symptoms, after completing 10 days of acyclovir and 7 days of flucloxacillin. At the 1 month follow-up, the patient revealed

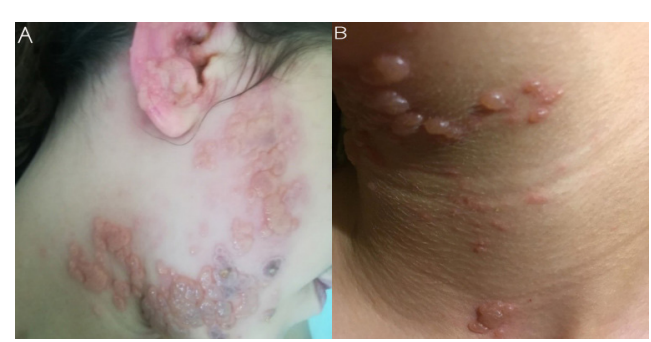

Figure 1 Vesiculo-maculopustular eruption: (A) on the right hemiface and ear with bacterial overinfection and (B) on the neck.

continuous skin improvement (figure 2B). One year later she still had some facial skin discolouration and mild scars (figure 2C). Immunity status screening was also repeated and was unremarkable (serum immunoglobulins, $\mathrm{T}$ and $\mathrm{B}$ lymphocyte counts and complement protein levels were within normal range for age. HIV was negative and the other serologies previously performed were almost identical, except VZV serologies which were IgG positive and IgM negative). The case described corresponds to an adolescent that presented clinical findings suggestive of $\mathrm{HZ}$ with significant skin involvement, followed by encephalitis. HZ is the clinical manifestation of a VZV infection. ${ }^{12}$ The signs are usually a vesicular rash and severe burning pain with typical distribution by dermatomes. ${ }^{23}$ Most commonly there is only one dermatome involved. When more than two dermatomes are involved, the likelihood of the patient having an underlying condition that compromises its immune status increases. ${ }^{1-3}$ Nonetheless, this is not mandatory and, in rare cases, it may occur in previously healthy patients. ${ }^{4}$ Our patient had four dermatomes involved, but no immunodeficiency was found on follow-up investigation. $\mathrm{HZ}$ patients usually develop scars due to the skin involvement, ${ }^{34}$ especially if the skin lesions are severe. These scars may be psychologically damaging (particularly for teenagers), but with proper treatment, even significant skin manifestations may have a complete resolution after several weeks or months. ${ }^{3} \mathrm{HZ}$ patients may

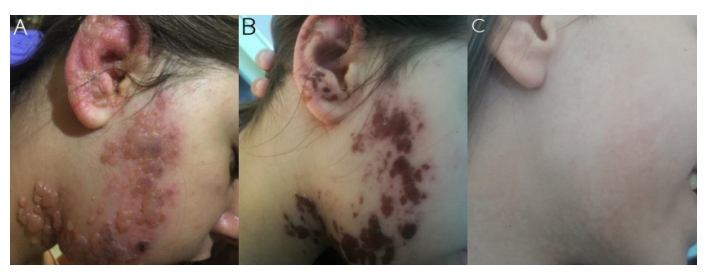

Figure 2 (A) 'Ice-pick' scar on the day of discharge, (B) 'ice-pick' scar 1 month after and (C) skin scars/ pigmentation 1 year late. 
also develop other complications, some with central nervous system involvement $\left(0.5-1.5 / 1000\right.$ patients) ${ }^{5}$ Encephalitis is an example of those. ${ }^{1245}$ Even though it rarely occurs, ${ }^{4}$ it is one of the most common causes of encephalitis in children. ${ }^{45}$ This should be kept in mind if a patient presents neurological symptoms, such as cognitive or behavioural changes. When this diagnosis is made, it requires the introduction of antiviral therapy as soon as possible to achieve a better prognosis. ${ }^{1-35}$

\section{Learning points}

- In the presence of cognitive and/or behavioural symptoms and vesicular skin rash we should consider varicella zoster encephalitis in the differential diagnosis.

- Encephalitis due to varicella-zoster virus is usually rare. However, it is one of the most common causes of encephalitis in the paediatric age.

- If more than two dermatomes are involved, the likelihood of the patient having an underlying condition that is compromising its immune status increases. This makes it important to assess the patient's immunity status.

- Scars are a common sequela of herpes zoster, but even significant skin manifestations might have a complete resolution after several months.
Contributors DHdS: Bibliographical search, elaboration of the article. DB: Elaboration of the article and critical reviewing of the content of the article. BM: critical reviewing of the content of the article. AGS: critical reviewing of the content of the article.

Funding The authors have not declared a specific grant for this research from any funding agency in the public, commercial or not-for-profit sectors.

Competing interests None declared.

Patient consent for publication Consent obtained from parent(s)/guardian(s).

Provenance and peer review Not commissioned; externally peer reviewed.

Case reports provide a valuable learning resource for the scientific community and can indicate areas of interest for future research. They should not be used in isolation to guide treatment choices or public health policy.

\section{ORCID iDs}

Diana H Silva http://orcid.org/0000-0002-6471-2096

Denise Banganho http://orcid.org/0000-0001-7899-8243

\section{REFERENCES}

1 Gershon AA, Breuer J, Cohen Jl, et al. Varicella zoster virus infection. Nat Rev Dis Primers 2015;1:15016.

2 Cohen Jl. Clinical practice: herpes zoster. N Engl J Med 2013;369:255-63.

3 Dworkin RH, Johnson RW, Breuer J, et al. Recommendations for the management of herpes zoster. Clin Infect Dis 2007;44 Suppl 1:S1-26.

4 Kennedy P, Gershon A, et al. Clinical features of varicella-zoster virus infection. Viruses 2018;10:609.

5 Grahn A, Studahl M. Varicella-Zoster virus infections of the central nervous system prognosis, diagnostics and treatment. J Infect 2015;71:281-93.

Copyright 2022 BMJ Publishing Group. All rights reserved. For permission to reuse any of this content visit

https://www.bmj.com/company/products-services/rights-and-licensing/permissions/

BMJ Case Report Fellows may re-use this article for personal use and teaching without any further permission.

Become a Fellow of BMJ Case Reports today and you can:

- Submit as many cases as you like

- Enjoy fast sympathetic peer review and rapid publication of accepted articles

- Access all the published articles

- Re-use any of the published material for personal use and teaching without further permission

Customer Service

If you have any further queries about your subscription, please contact our customer services team on +44 (0) 2071111105 or via email at support@bmj.com.

Visit casereports.bmj.com for more articles like this and to become a Fellow 